\title{
Effect of Integrated Nutrient Management on Growth and Yield of Fennel (Foeniculum vulgare Mill.)
}

\author{
M.V. Kusuma*, J. Venkatesha, P.M. Ganghadarappa., J.S. Hiremath, \\ A.B. Mastiholi and G. Manjunatha
}
Department of Plantation, Spices, Medicinal and Aromatic Crops, Kittur Rani Channamma College of Horticulture, Arabhavi, University of Horticultural Sciences, Bagalkot, India

*Corresponding author

\section{Keywords \\ Organic and inorganic sources, $\mathrm{N}$ equivalent application, Bio fertilizers, Fennel \\ Article Info \\ Accepted: \\ 17 December 2018 \\ Available Online: \\ 10 January 2019}

\section{A B S T R A C T}

A field experiment was conducted at research block of the Department of Plantation, Spices, Medicinal and Aromatic Crops, Kittur Rani Channamma College of Horticulture, Arabhavi, Belagavi district during rabi-2015-16 and 2016-17 to study the effect of integrated nutrient management on growth and yield of fennel (Foeniculum vulgare Mill.). The experiment was laid out in randomized complete block design and treatments were replicated thrice. The experiment consisted of twelve treatments. Among the different treatments, significantly higher seed yield per plant and hectare was recorded with $\mathrm{T}_{6}$ RDFYM+ $75 \% \mathrm{RDN}+\mathrm{RDPK}+$ Azospirillum at $5 \mathrm{~kg} \mathrm{ha}^{-1}+\mathrm{PSB}$ at $3 \mathrm{~kg} \mathrm{ha}^{-1}(30.47 \mathrm{~g}$ plant $^{-1}$ and $2.29 \mathrm{t} \mathrm{ha}^{-1}$, respectively) this was on par with $\mathrm{T}_{4^{-}}$vermicompost at $2.5 \mathrm{t} \mathrm{ha}^{-1}+$ RDNPK+ Azospirillum at $5 \mathrm{~kg} \mathrm{ha}^{-1}+\mathrm{PSB}$ at $3 \mathrm{~kg} \mathrm{ha}^{-1}\left(29.85 \mathrm{~g} \mathrm{plant}^{-1}, 1.44 \mathrm{~kg} \mathrm{plot}^{-1}\right.$ and $2.21 \mathrm{t} \mathrm{ha}^{-1}$, respectively). Significantly higher growth and yield parameters viz., plant height $(209.97 \mathrm{~cm})$, number of primary and secondary branches (16.43 and 7.50, respectively), maximum number of umbels per plant (29.24), number of umbellets per umbel (23.68), number of seeds per umbellate (35.07) and test weight (7.35 g) were recorded with treatment receiving $\mathrm{T}_{6}-\mathrm{RDFYM}+75 \% \mathrm{RDN}+\mathrm{RDPK}+$ Azospirillum at 5 $\mathrm{kg} \mathrm{ha}^{-1}+\mathrm{PSB}$ at $3 \mathrm{~kg} \mathrm{ha}^{-1}$.

\section{Introduction}

Among the spices, seed spices are the group, which denotes all those annuals whose dried fruit or seeds are used as spices. The seed spices are aromatic vegetable products of tropical origin and are commonly used in pulverized form, primarily for seasoning or garnishing the foods and beverages. They are also used in preparation of various value added products viz., spice oils, oleoresins and spice powders. Seed spices also have industrial importance and are used in various pharmaceutical preparations and medicines. Seed spices contribute about 50 per cent of total area and 20 per cent of production of spices in the country. Presently, 17.40 lakh hectares of area is under seed spices cultivation with a production of 14.54 lakh tonnes annually. 
Fennel is one of the important major seed spice crops, botanically named as (Foeniculum vulgare Mill. or Foeniculum officinale All.), belongs to the family Umbelliferae (Apiaceae) and having chromosome number of $2 n=22$. The generic name derives from the Latin "foenum", which means 'hay', referring to the foliar structure. It is a well known aromatic medicinal plant used in traditional medicine and also as spice and substrate for different industrial purpose (Telci et al., 2009). Vernacularly it is called Saunf or Badi Saunf. Fennel is a digestive adjuent, highly aromatic and flavorful herb with culinary uses. In India, it's seeds are used for mastication and chewing alone or with betel leaves. Fennel is believed to be native of Southern Europe and Mediterranean region. It is widely cultivated throughout the temperate and subtropical region of the world. In India fennel is mainly grown in Gujarat and Rajasthan and to some extent in Uttar Pradesh, Karnataka, Andhra Pradesh, Punjab, Madhya Pradesh, Bihar, Haryana and Jammu and Kashmir as a winter crop covering a total Among these seed spices, fennel is cultivated in an area of 0.75 lakh hectares with a production of 1.25 lakh tonnes with an average productivity of 1.66 tonnes per hectare (Anon., 2018).

Integrated nutrient management includes use of organic manure/ compost, bio- fertilizer, chemical fertilizer, green manuring, residue management, legume based cropping system, use of nutrient - responsive varieties, proper method and time of organic manure and fertilizer application, soil and water management to minimize the nutrient losses occurring through volatilization, denitrification, runoff and leaching. Application of plant nutrients in proper balance form is also a part of integrated plant nutrient management (IPNM) system. Supply of nutrients to seed spices in appropriate quantities and at the correct time is essential for economically and environmentally sustainable agriculture. Soil organic matter, crop residues and manures play a vital role in the supply of macro and micronutrients and the transformation between the various organic and inorganic forms often control availability, both for plant uptake and loss to environment (Aishwath and Vashistha, 2008 and Lal et al., 2009).

\section{Materials and Methods}

A field experiment was conducted at research block of the Department of Plantation, Spices, Medicinal and Aromatic Crops, Kittur Rani Channamma College of Horticulture, Arabhavi, Belagavi district which is situated in Northern Dry Zone of Karnataka at a latitude of $16^{\circ} 15^{\prime} \mathrm{N}$ latitude and $94^{\circ} 45^{\prime} \mathrm{E}$ longitude and at an altitude of $612 \mathrm{~m}$ above Mean Sea Level (MSL). The experiment was conducted to study the effect of growth regulators on growth and yield of fennel (Foeniculum vulgare Mill.) cv. Gujarat Fennel 1 during rabi - 2015-16 and 2016-17 with irrigated condition. The experiment was laid out in split plot design and treatments were replicated thrice. The net plot size was $1.8 \mathrm{~m} \times$ $1.8 \mathrm{~m}\left(3.24 \mathrm{~m}^{2}\right)$. Recommended dose of nutrients for fennel is 90:60:30 N: $\mathrm{P}_{2} \mathrm{O}_{5}: \mathrm{K}_{2} \mathrm{O}$ $\mathrm{kg} \mathrm{ha}^{-1}$. The experiment consisted of twelve treatments and treatment details were as follows- $\mathrm{T}_{1}$ - RDFYM (15 $\left.\mathrm{t} \mathrm{ha}^{-1}\right)+$ RDNPK (90:60:30 kg ha ${ }^{-1}$ ), T $2^{-}$RDFYM+ RDNPK + Azospirillum at $5 \mathrm{~kg} \mathrm{ha}^{-1}+\mathrm{PSB}$ at $3 \mathrm{~kg} \mathrm{ha}^{-1}$, $\mathrm{T}_{3}-\mathrm{RDFYM}+\mathrm{RDNPK}+$ Azotobacter at $5 \mathrm{~kg}$ $\mathrm{ha}^{-1}+\mathrm{PSB}$ at $3 \mathrm{~kg} \mathrm{ha}^{-1}, \mathrm{~T}_{4^{-}}$Vermicompost 2.5 $\mathrm{t} \mathrm{ha}^{-1}+\mathrm{RDNPK}+$ Azospirillum at $5 \mathrm{~kg}$ $\mathrm{ha}^{-1}+\mathrm{PSB}$ at $3 \mathrm{~kg} \mathrm{ha}^{-1}, \mathrm{~T}_{5^{-}}$RDFYM+ $75 \%$ $\operatorname{RDN}\left(67.5 \mathrm{~kg} \mathrm{ha}^{-1}\right)+\operatorname{RDPK}\left(60: 30 \mathrm{~kg} \mathrm{ha}^{-1}\right)+$ $25 \% \mathrm{~N}$ equivalent of FYM $\left(4.5 \mathrm{t} \mathrm{ha}^{-1}\right), \mathrm{T}_{6^{-}}$ $\mathrm{RDFYM}+75 \% \mathrm{RDN}+\mathrm{RDPK}+$ Azospirillum at $5 \mathrm{~kg} \mathrm{ha}^{-1}+\mathrm{PSB}$ at $3 \mathrm{~kg} \mathrm{ha}^{-1}, \mathrm{~T}_{7}-\mathrm{RDFYM}+$ $75 \% \mathrm{RDN}+\mathrm{RDPK}+$ Azotobacter at $5 \mathrm{~kg} \mathrm{ha}^{-1}$ $+\mathrm{PSB}$ at $3 \mathrm{~kg} \mathrm{ha}{ }^{-1}, \mathrm{~T}_{8^{-}}$RDFYM+ $50 \%$ RDNPK (45:30:15 kg ha $\left.{ }^{-1}\right), \mathrm{T}_{9^{-}}$RDFYM + $50 \% \mathrm{RDN}+\mathrm{RDPK}+50 \% \mathrm{~N}$ equivalent of 
FYM (9 t ha $\left.{ }^{-1}\right), \mathrm{T}_{10^{-}}$RDFYM + 50\% RDN + $\mathrm{RDPK}+$ Azospirillum at $5 \mathrm{~kg} \mathrm{ha}^{-1}+\mathrm{PSB}$ at 3 $\mathrm{kg} \mathrm{ha}{ }^{-1}, \mathrm{~T}_{11^{-}}$RDFYM $+50 \%$ RDNPK + Azospirillum at $5 \mathrm{~kg} \mathrm{ha}^{-1}+\mathrm{PSB}$ at $3 \mathrm{~kg} \mathrm{ha}^{-1}$, $\mathrm{T}_{12^{-}} \mathrm{RDFYM}+50 \% \mathrm{RDN}+\mathrm{RDPK}+$ Azotobacter at $5 \mathrm{~kg} \mathrm{ha}^{-1}+$ PSB at $3 \mathrm{~kg} \mathrm{ha}^{-1}$. Treatments were imposed as per the treatment combinations. Soil of the experimental site was red sandy loam with a $\mathrm{pH}$ of $7.56, \mathrm{EC}$ $\left(0.22 \mathrm{dSm}^{-1}\right)$, low in organic carbon $(0.52 \%)$ and low in available nitrogen $\left(160.54 \mathrm{~kg} \mathrm{ha}^{-1}\right)$, medium in $\mathrm{P}_{2} \mathrm{O}_{5}\left(27.57 \mathrm{~kg} \mathrm{ha}^{-1}\right)$ and low in $\mathrm{K}_{2} \mathrm{O} \quad\left(196 \mathrm{~kg} \mathrm{ha}^{-1}\right)$. Experimental data collected was subjected to statistical analysis by adopting Fisher's method of analysis of variance (ANOVA) as outlined in Gomez and Gomez (1984). Critical difference (CD) values were calculated whenever the " $F$ " test was significant at 5 per cent level.

\section{Results and Discussion}

Optimum growth, productivity and quality of any crop are influenced by several factors of which genetic constitution of the variety, environmental factors and agro- techniques adopted play a vital role. Although, every plant has its own specific inherent characters and genetic potential which are fully expressed only when they have favourable environment conditions. In modern production technology, great emphasis is being given for choosing appropriate variety and density of plant population in order to boost up the production per unit area besides adopting integrated nutrient management practices through organic and inorganic which enhances growth, yield and quality of the crop. Integrated nutrient management practices help in maintaining soil health and reduces the cost of inputs.

\section{Effect of INM practices on growth parameters of fennel}

The vegetative growth parameters viz., plant height, number of primary and secondary branches, plant spread and total dry matter production differed significantly among the treatments at all the stages of crop growth during two consecutive years (Table 1 and 2). Plants supplied with RDFYM+ 75\% RDN + $\mathrm{RDPK}+$ Azospirillum $5 \mathrm{~kg} \mathrm{ha}^{-1}+\mathrm{PSB} 3 \mathrm{~kg}$ $\mathrm{ha}^{-1}\left(\mathrm{~T}_{6}\right)$ resulted in maximum plant height $(209.97 \mathrm{~cm})$ at harvesting stage. The reason for better growth and development under this treatment could be attributed to increased availability of nitrogen to the plants initially through inorganic fertilizer and later by FYM/ organic sources, matching to the need of plants throughout the cropping season.

The superiority of combination, but nitrogen through inorganic source might be due to added advantage of FYM, which besides supplying all the essential nutrients, also improves physical conditions of soil in respect of granulation, friability, porosity and water holding capacity which enable the crop to utilize nutrients and water more efficiently especially under light textured loamy sand soils (Yadav, 2005). Nitrogen being the main constituent of protein and nucleic acid, which greatly influences the cell division, cell elongation and cell enlargement and thereby it could increase the shoot length. Moreover, Azospirillum enhanced the activity of growth hormones like IAA, GA and dehydrozeatin, which promotes the vegetative growth. This was also related to application of recommended dose of $\mathrm{N}, \mathrm{P}$ and $\mathrm{K}$ through fertilizers enhanced the availability of nutrients, which resulted in increased photosynthetic activity and translocation of photosynthates from source to sink and resulted in increased plant growth. Godara et al., (2014) also recorded higher growth and yield attributes when RDF was applied through chemical fertilizers in fennel followed by integrated nutrient management. These phytohormones might have caused proliferation of roots and thereby increased the uptake of nutrients resulted in better plant height. This is in conformity with the findings 
of Dadkhah (2012). Increased growth could be correlated to suitable combination of organic and inorganic source of nutrients which ensured readily availability of nutrients for initial requirement through inorganic source and slow pace as long term availability through organic source and resulted in higher plant height, branches per plant, plant spread and dry matter production (Choudhary et al., 2011).

Increased growth was also related to suitable combination of organic and inorganic nitrogenous fertilizer maintained the sustainable soil fertility in soil and enhances high level of productivity (Pillai et al., 1985). Increase in growth parameters can be attributed to the positive effect of biofertilizers on nutrient uptake by plants (Gad, 2001).

Maximum number of primary and secondary branches (16.43 and 7.50, respectively) were recorded in plant supplied with RDFYM+ $75 \% \mathrm{RDN}+\mathrm{RDPK}+$ Azospirillum at $5 \mathrm{~kg}$ ha ${ }^{1}+\mathrm{PSB}$ at $3 \mathrm{~kg} \mathrm{ha}^{-1}\left(\mathrm{~T}_{6}\right)$ followed by $\mathrm{T}_{4}$ and $\mathrm{T}_{2}$ (15.50 and 14.87, respectively) (Table 2). This could be attributed to the application of FYM with chemical fertilizers and bio-fertilizers. The growth promoting effect of FYM as a source of plant nutrients and humus, improved the soil physical conditions by increasing its capacity to absorb and store water, improving aeration and favouring beneficial microbial activity is well established. Besides, biofertilizers had the similar effects of hormones create favourable effect on active root rhizosphere and helps for better uptake of nutrients which helps growth of plants.

These phytohormones might have caused proliferation of roots and increased the uptake of nutrients which helped in fast multiplication of cells and cellular elongation resulting in better growth of roots and shoots which helped better vegetative growth including plant height, plant spread and number of primary and secondary branches. These results are in conformity with the finding of Kaushik et al., 2000 and De Salamone et al., 2001, Meena, 2001, Joy et al., 2005, Naveen, 2010 and Dadkhah, 2012.

Dry matter production was significantly differed by integrated nutrient management practices in fennel during both the years (Table 2). The maximum dry matter production was recorded with RDFYM+ $\mathrm{RDNPK}+$ Azospirillum at $5 \mathrm{~kg} \mathrm{ha}^{-1}+\mathrm{PSB}$ at 3 $\mathrm{kg} \mathrm{ha}^{-1}\left(\mathrm{~T}_{2}\right)\left(170.33 \mathrm{~g}\right.$ plant $^{-1}$ and $\left.12.62 \mathrm{t} \mathrm{ha}^{-1}\right)$ which was on par with Vermicompost at 2.5 at $\mathrm{t} \mathrm{ha}{ }^{-1}+\mathrm{RDNPK}+$ Azospirillum at $5 \mathrm{~kg} \mathrm{ha}^{-1}$ $+\mathrm{PSB}$ at $3 \mathrm{~kg} \mathrm{ha}^{-1}\left(\mathrm{~T}_{4}\right)$ and RDFYM+ $75 \%$ $\mathrm{RDN}+\mathrm{RDPK}+$ Azospirillum at $5 \mathrm{~kg} \mathrm{ha}^{-1}$ + PSB at $3 \mathrm{~kg} \mathrm{ha}^{-1}\left(\mathrm{~T}_{6}\right)$ (170.00 $\mathrm{g} \mathrm{plant}^{-1}$ and $12.59 \mathrm{t} \mathrm{ha}^{-1}$, respectively).

The increased dry matter production could be attributed to better vegetative growth and production of more fresh weight. Better uptake of nutrients due to influence of biofertilizers supplied along with chemical fertilizers and organic manures. The better absorption and accumulation of nutrients promotes growth and metabsolism. Effect of biofertilizer on the dry weight of plant was due to increased nitrogen uptake and the growth rate improvement. Effect of biostimulant on the dry weight of plant was due to increased nitrogen uptake. This in turn resulted in production of more dry matter (Mahfouz and Sharaf Eldin, 2007). The effectiveness of vermicompost in increasing the dry weight of plant could be attributed to increased the growth rate because of the better water and mineral uptake such as nitrogen and phosphorus (Arancon et al., 2006; Zaller, 2007), which leads to the improvement in dry weight of plant. The result of present finding are in agreement with the reports of Meena et al., (2009), Moradi et al., (2011), Darzi (2012) in fennel crop and Bajya et al., (2017) fennel crop. 
Table.1 Plant height, number of primary and secondary branches of fennel as influence by integrated nutrient management practices

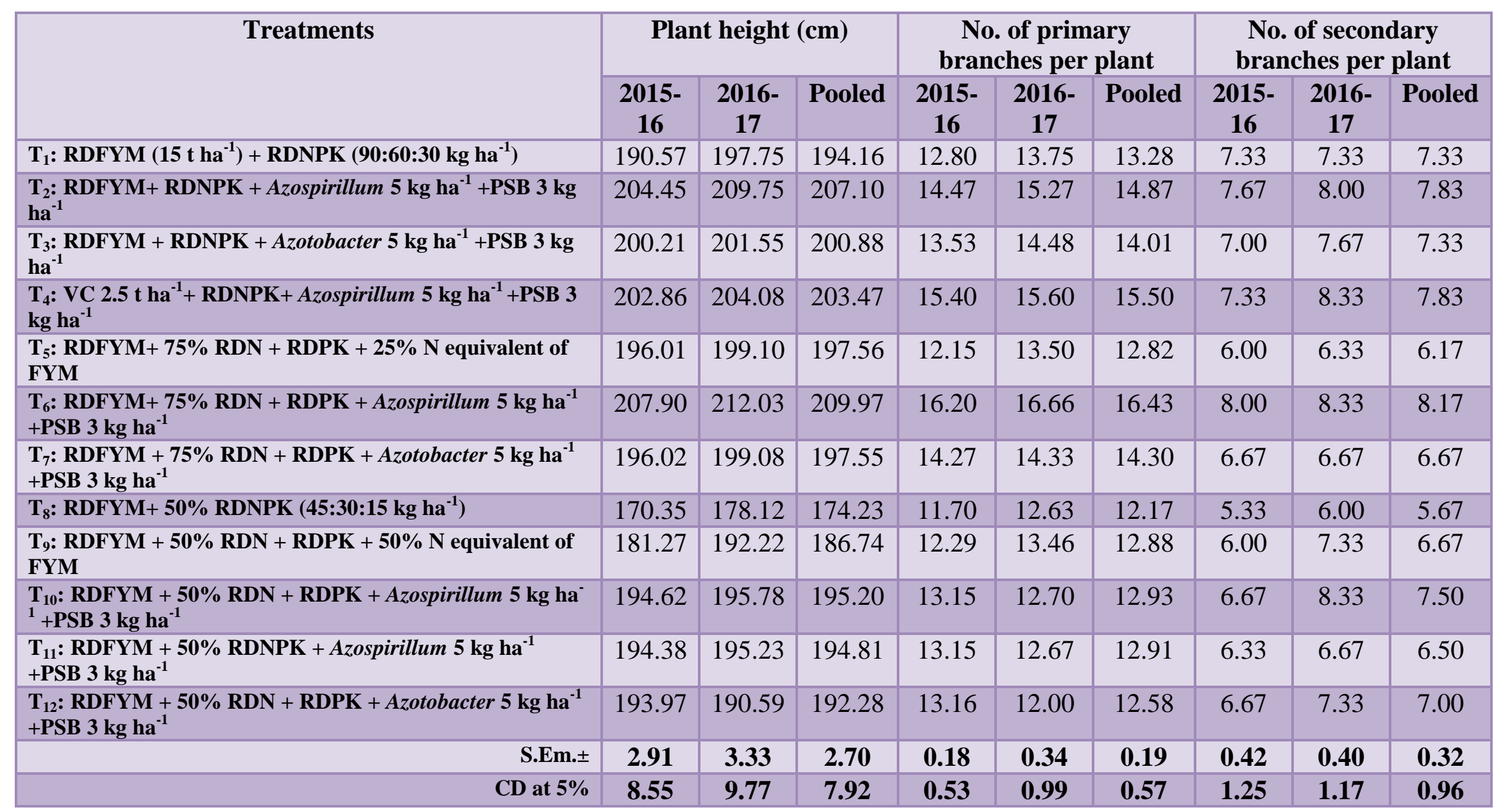


Table.2 Plant spread and total dry matter production of fennel as influence by integrated nutrient management practices

\begin{tabular}{|c|c|c|c|c|c|c|c|c|c|}
\hline \multirow[t]{2}{*}{ Treatments } & \multicolumn{3}{|c|}{$\begin{array}{l}\text { Plant spread }\left(\mathrm{cm}^{2}\right) \\
\text { (North- South) }\end{array}$} & \multicolumn{3}{|c|}{$\begin{array}{l}\text { Plant spread }\left(\mathrm{cm}^{2}\right) \\
\quad(\text { East- West) }\end{array}$} & \multicolumn{3}{|c|}{$\begin{array}{l}\text { Total dry matter } \\
\text { production }\left(\text { g plant }^{-1}\right)\end{array}$} \\
\hline & $\begin{array}{l}2015- \\
16\end{array}$ & $\begin{array}{l}\text { 2016- } \\
17\end{array}$ & Pooled & $\begin{array}{l}2015- \\
16\end{array}$ & $\begin{array}{c}2016- \\
17\end{array}$ & Pooled & $\begin{array}{l}2015- \\
16\end{array}$ & $\begin{array}{c}2016- \\
17\end{array}$ & Pooled \\
\hline$T_{1}: \operatorname{RDFYM}\left(15 \mathrm{t} \mathrm{ha}^{-1}\right)+\operatorname{RDNPK}\left(90: 60: 30 \mathrm{~kg} \mathrm{ha}^{-1}\right)$ & 56.01 & 58.10 & 57.06 & 64.27 & 66.57 & 65.42 & 158.33 & 163.00 & 160.67 \\
\hline $\begin{array}{l}\mathrm{T}_{2}: \text { RDFYM+ RDNPK + Azospirillum } 5 \mathrm{~kg} \mathrm{ha}^{-1}+\text { PSB } 3 \mathrm{~kg} \\
\text { ha }^{-1}\end{array}$ & 55.97 & 58.03 & 57.00 & 65.17 & 66.27 & 65.72 & 165.00 & 175.67 & 170.33 \\
\hline $\begin{array}{l}\mathrm{T}_{3}: \text { RDFYM + RDNPK + Azotobacter } 5 \mathrm{~kg} \mathrm{ha}^{-1}+\text { PSB } 3 \mathrm{~kg} \\
\text { ha }^{-1}\end{array}$ & 54.87 & 57.35 & 56.11 & 64.67 & 65.87 & 65.27 & 162.33 & 132.83 & 147.58 \\
\hline $\begin{array}{l}\mathrm{T}_{4}: \text { VC } 2.5 \mathrm{t} \mathrm{ha}^{-1}+\text { RDNPK+ Azospirillum } 5 \mathrm{~kg} \mathrm{ha}^{-1}+\text { PSB } 3 \\
\mathrm{~kg} \mathrm{ha}^{-1}\end{array}$ & 59.70 & 58.57 & 59.13 & 65.77 & 66.90 & 66.33 & 164.67 & 175.33 & 170.00 \\
\hline $\begin{array}{l}\mathrm{T}_{5}: \mathrm{RDFYM}+75 \% \mathrm{RDN}+\mathrm{RDPK}+25 \% \mathrm{~N} \text { equivalent of } \\
\text { FYM }\end{array}$ & 54.57 & 55.80 & 55.18 & 62.15 & 64.93 & 63.54 & 151.00 & 162.33 & 156.67 \\
\hline $\begin{array}{l}\text { T }_{6}: \text { RDFYM+ } 75 \% \text { RDN + RDPK + Azospirillum } 5 \mathrm{~kg} \mathrm{ha}^{-1} \\
+ \text { PSB } 3 \mathrm{~kg} \mathrm{ha}^{-1}\end{array}$ & 60.57 & 60.07 & 60.32 & 69.83 & 71.00 & 70.42 & 165.00 & 175.00 & 170.00 \\
\hline $\begin{array}{l}\text { T }_{7}: \text { RDFYM + } 75 \% \text { RDN + RDPK + Azotobacter } 5 \mathrm{~kg} \mathrm{ha}^{-1} \\
+ \text { PSB } 3 \mathrm{~kg} \mathrm{ha}^{-1}\end{array}$ & 58.37 & 59.17 & 58.77 & 66.83 & 67.47 & 67.15 & 160.00 & 170.67 & 165.33 \\
\hline$T_{8}:$ RDFYM+ 50\% RDNPK (45:30:15 $\left.\mathrm{kg} \mathrm{ha}^{-1}\right)$ & 54.00 & 55.40 & 54.70 & 60.80 & 65.17 & 62.98 & 148.00 & 155.67 & 151.83 \\
\hline $\begin{array}{l}\text { T}_{9}: \text { RDFYM }+50 \% \text { RDN + RDPK }+50 \% \mathrm{~N} \text { equivalent of } \\
\text { FYM }\end{array}$ & 56.56 & 57.20 & 56.88 & 65.28 & 66.93 & 66.11 & 158.67 & 165.67 & 162.17 \\
\hline $\begin{array}{l}\text { T}_{10}: \text { RDFYM + } 50 \% \text { RDN + RDPK + Azospirillum } 5 \mathrm{~kg} \mathrm{ha}^{-} \\
{ }^{1}+\text { PSB } 3 \mathrm{~kg} \mathrm{ha}^{-1}\end{array}$ & 57.01 & 58.58 & 57.80 & 66.79 & 67.60 & 67.20 & 161.67 & 166.33 & 164.00 \\
\hline $\begin{array}{l}\text { T11 }_{11} \text { RDFYM + } 50 \% \text { RDNPK + Azospirillum } 5 \mathrm{~kg} \mathrm{ha}^{-1} \\
+ \text { PSB } 3 \mathrm{~kg} \mathrm{ha}^{-1}\end{array}$ & 56.13 & 56.73 & 56.43 & 66.13 & 67.37 & 66.75 & 158.67 & 164.00 & 161.33 \\
\hline $\begin{array}{l}\text { T12 }_{12} \text { RDFYM + } 50 \% \text { RDN + RDPK + Azotobacter } 5 \mathrm{~kg} \mathrm{ha}^{-1} \\
+ \text { PSB } 3 \mathrm{~kg} \mathrm{ha}^{-1}\end{array}$ & 55.00 & 58.97 & 56.98 & 66.67 & 68.10 & 67.38 & 159.00 & 160.67 & 159.83 \\
\hline S.Em. \pm & 0.36 & 0.29 & 0.21 & 0.31 & 0.37 & 0.26 & 0.79 & 0.86 & 0.62 \\
\hline CD at $5 \%$ & 1.05 & 0.86 & 0.62 & 0.91 & 1.09 & 0.77 & 2.32 & 2.53 & 1.84 \\
\hline
\end{tabular}


Table.3 Number of umbels per plant, no. of umbellets per umbel and no. of seeds per umbellet in fennel as influenced by integrated nutrient management

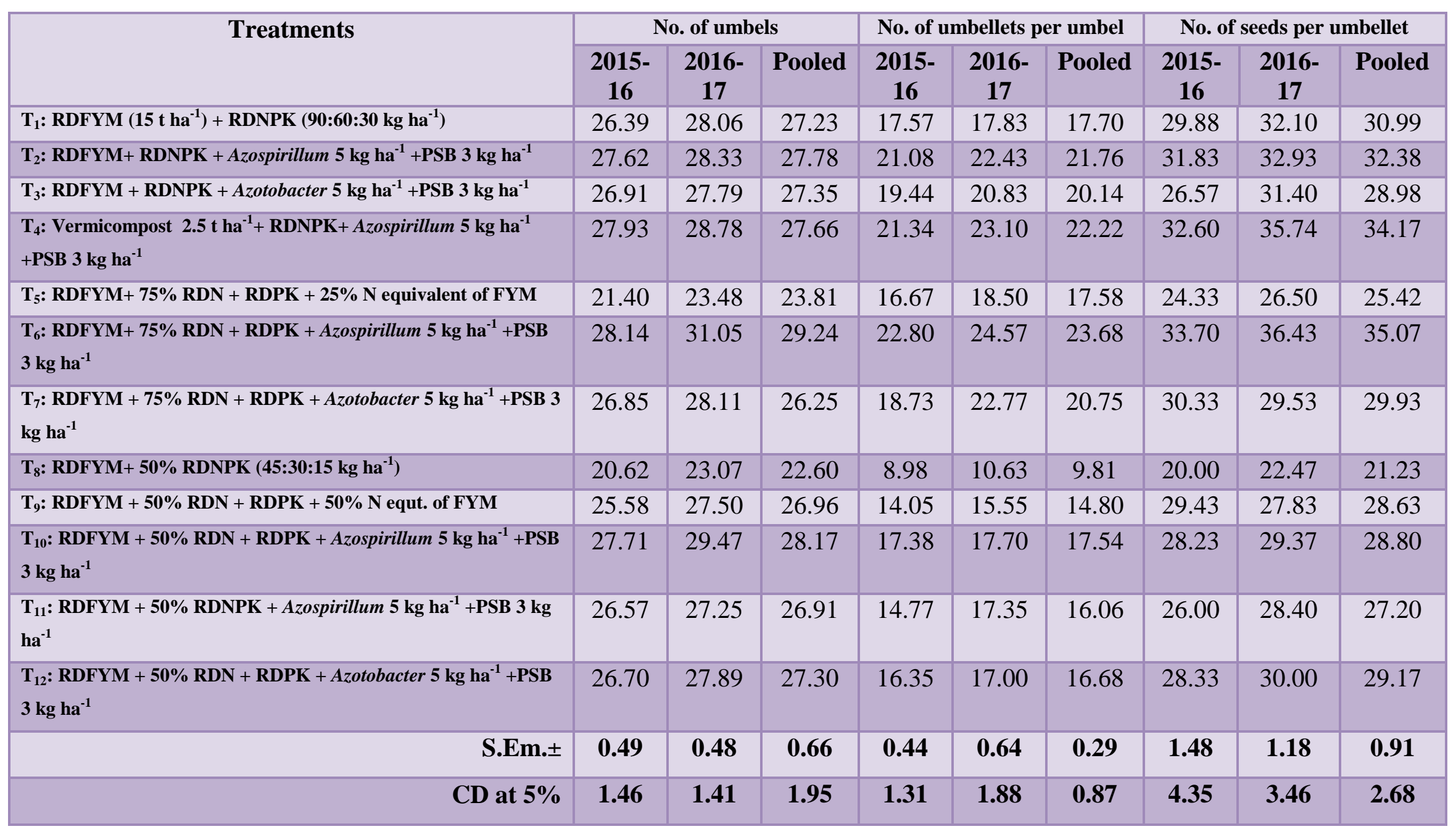


Table.4 Effect of integrated nutrient management on seed yield per plant $(\mathrm{g})$, seed yield per plot $(\mathrm{kg})$ and seed yield per hectare $(\mathrm{t})$ in fennel

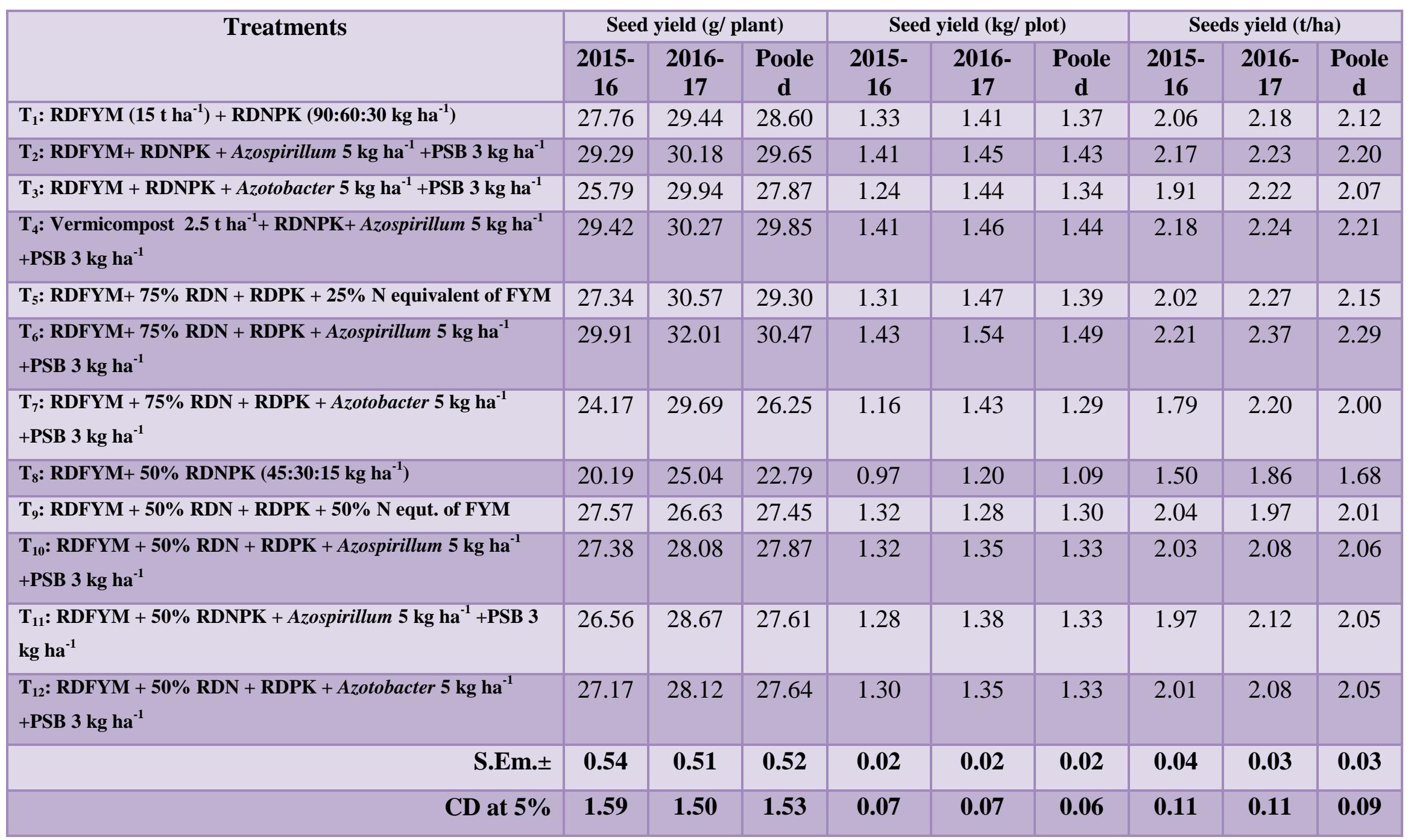


Table.5 Test weight $(\mathrm{g})$ and harvest index $(\%)$ as influenced by integrated nutrient management in fennel

\begin{tabular}{|c|c|c|c|c|c|c|}
\hline \multirow{2}{*}{ Treatments } & \multicolumn{3}{|c|}{ Test weight (g) } & \multicolumn{3}{|c|}{ Harvest index (\%) } \\
\hline & 2015-16 & 2016-17 & Pooled & 2015-16 & 2016-17 & Pooled \\
\hline$T_{1}: \operatorname{RDFYM}\left(15 \mathrm{t} \mathrm{ha}^{-1}\right)+\operatorname{RDNPK}\left(90: 60: 30 \mathrm{~kg} \mathrm{ha}^{-1}\right)$ & 7.02 & 7.18 & 7.10 & 17.96 & 18.68 & 18.32 \\
\hline $\mathrm{T}_{2}:$ RDFYM+ RDNPK + Azospirillum $5 \mathrm{~kg} \mathrm{ha}^{-1}+\mathrm{PSB} 3 \mathrm{~kg} \mathrm{ha}^{-1}$ & 7.07 & 6.90 & 6.98 & 17.15 & 17.56 & 17.36 \\
\hline$T_{3}:$ RDFYM + RDNPK + Azotobacter $5 \mathrm{~kg} \mathrm{ha}^{-1}+$ PSB $3 \mathrm{~kg} \mathrm{ha}^{-1}$ & 6.34 & 7.02 & 6.68 & 15.28 & 22.55 & 18.91 \\
\hline $\begin{array}{l}\mathrm{T}_{4} \text { : Vermicompost } 2.5 \mathrm{t} \mathrm{ha}^{-1}+\text { RDNPK+ Azospirillum } 5 \mathrm{~kg} \mathrm{ha}^{-1}+\text { PSB } 3 \\
\mathrm{~kg} \mathrm{ha}^{-1}\end{array}$ & 6.56 & 7.05 & 6.81 & 18.76 & 19.17 & 18.97 \\
\hline$T_{5}:$ RDFYM+ $75 \%$ RDN + RDPK + 25\% N equivalent of FYM & 6.86 & 6.64 & 6.75 & 20.08 & 18.20 & 19.14 \\
\hline $\begin{array}{l}\text { T6: RDFYM+ } 75 \% \text { RDN + RDPK + Azospirillum } 5 \mathrm{~kg} \mathrm{ha}^{-1}+\mathrm{PSB} 3 \mathrm{~kg} \\
\mathrm{ha}^{-1}\end{array}$ & 7.33 & 7.36 & 7.35 & 19.34 & 19.62 & 19.48 \\
\hline $\begin{array}{l}\text { T }_{7}: \text { RDFYM + } 75 \% \text { RDN + RDPK + Azotobacter } 5 \mathrm{~kg} \mathrm{ha}^{-1}+\text { PSB } 3 \text { kg } \\
\text { ha }^{-1}\end{array}$ & 6.65 & 7.00 & 6.83 & 15.11 & 17.40 & 16.25 \\
\hline$T_{8}:$ RDFYM+ 50\% RDNPK (45:30:15 kg ha $\left.{ }^{-1}\right)$ & 5.81 & 6.04 & 5.93 & 13.64 & 17.43 & 15.53 \\
\hline$T_{9}:$ RDFYM + 50\% RDN + RDPK + 50\% N equt. of FYM & 6.31 & 6.92 & 6.61 & 20.10 & 18.15 & 19.13 \\
\hline $\begin{array}{l}\text { T10: RDFYM + 50\% RDN + RDPK + Azospirillum } 5 \mathrm{~kg} \mathrm{ha}^{-1}+\text { PSB } 3 \mathrm{~kg} \\
\text { ha }^{-1}\end{array}$ & 6.56 & 6.86 & 6.71 & 18.18 & 16.80 & 17.49 \\
\hline T $_{11}:$ RDFYM + 50\% RDNPK + Azospirillum $5 \mathrm{~kg} \mathrm{ha}^{-1}+$ PSB $3 \mathrm{~kg} \mathrm{ha}^{-1}$ & 6.34 & 6.76 & 6.55 & 16.38 & 17.89 & 17.13 \\
\hline $\begin{array}{l}\text { T12: RDFYM + 50\% RDN + RDPK + Azotobacter } 5 \mathrm{~kg} \mathrm{ha}^{-1}+\text { PSB } 3 \mathrm{~kg} \\
\text { ha }^{-1}\end{array}$ & 7.02 & 6.86 & 6.94 & 17.72 & 17.50 & 17.61 \\
\hline 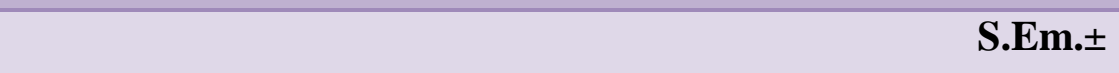 & 0.16 & 0.11 & 0.10 & 1.00 & 0.63 & 0.50 \\
\hline CD at $5 \%$ & 0.47 & 0.32 & 0.29 & 2.95 & 1.85 & 1.47 \\
\hline
\end{tabular}


Effect of INM practices on yield and yield parameters of fennel

The significantly higher seed yield per plant, plot and hectare was recorded with $\mathrm{T}_{6^{-}}$ RDFYM+ 75\% RDN + RDPK + Azospirillum at $5 \mathrm{~kg} \mathrm{ha}^{-1}+\mathrm{PSB}$ at $3 \mathrm{~kg} \mathrm{ha}^{-1}$ (30.47 $\mathrm{g} \mathrm{plant}^{-1}$, $1.49 \mathrm{~kg} \mathrm{plot}^{-1}$ and $2.29 \mathrm{t} \mathrm{ha}^{-1}$, respectively) this was on par with $\mathrm{T}_{4}$ - vermicompost at $2.5 \mathrm{t}$ $\mathrm{ha}^{-1}+$ RDNPK + Azospirillum at $5 \mathrm{~kg} \mathrm{ha}^{-1}$ $+\mathrm{PSB}$ at $3 \mathrm{~kg} \mathrm{ha}^{-1}\left(29.85 \mathrm{~g}^{-1}\right.$ plant $^{-1}, 1.44 \mathrm{~kg}$ plot $^{-1}$ and $2.21 \mathrm{t} \mathrm{ha}^{-1}$, respectively) (Table 4). Increased seed yield could be owing to the improvement of yield components such as umbel number per plant, test weight and dry weight of plant. The organic sources of fertilizer is not only supplies the major nutrients but also minor nutrients which might have played crucial role in enzymatic reactions in rhizosphere of the plant and thus helped the plant to produce better growth and yield attributes lead to produce more yield. The important reason responsible for better production of yield components and yield could be the supply of nutrients in balanced amount and available form. The increased growth in term of plant height, branches per plant, expansion of leaf lamina and chlorophyll content provided greater sites for photosynthesis and diversion of photosynthates towards sink (umbels and seed). The beneficial effect on yield attributes might be also due to increased supply of all the essential nutrients by FYM which might have resulted in higher synthesis of food and its subsequent partitioning to sink. The increased yield might also be owing to better nutritional status of the soil which might have stimulated the rate of various plant physiological processes which lead to increased yield attributing characteristics and their cumulative effect resulted in enhanced seed yields of fennel. These findings of present investigation are in conformity of the results of Rahman et al., (1990), Vadiraj et al., (1998), Bhat and Sulikeri (1992), Baboo and Rana (1995), Tiwari and Banafar (1995), Gaur (1998), Tripathi et al., (2001), Kumar et al., (2002), Rai et al., (2002), Khoja (2004), Meena (2005) and Singh (2013) in coriander.

Yield is the manifestation of growth and yield parameters. Plants supplied with RDFYM+ $75 \% \mathrm{RDN}+\mathrm{RDPK}+$ Azospirillum at $5 \mathrm{~kg} \mathrm{ha}{ }^{-}$ $1+\mathrm{PSB}$ at $3 \mathrm{~kg} \mathrm{ha}^{-1}\left(\mathrm{~T}_{6}\right)$ was recorded maximum number of umbels per plant (29.24) which was on par with $\mathrm{T}_{10}, \mathrm{~T}_{2}, \mathrm{~T}_{4}$ and $\mathrm{T}_{12}$ (28.17, 27.78, 27.66 and 27.30, respectively), maximum number of umbellets per umbel (23.68) and maximum number of seeds per umbellate (35.07) this was on par with $\mathrm{T}_{4^{-}}$ Vermicompost $2.5 \quad \mathrm{t} \quad \mathrm{ha}^{-1}+$ RDNPK+ Azospirillum at $5 \mathrm{~kg} \mathrm{ha}^{-1}+\mathrm{PSB} 3 \mathrm{~kg} \mathrm{ha}^{-1}$ and $\mathrm{T}_{2}$ - RDFYM+ RDNPK + Azospirillum at $5 \mathrm{~kg}$ $\mathrm{ha}^{-1}+\mathrm{PSB}$ at $3 \mathrm{~kg} \mathrm{ha}^{-1}$ (34.17 and 32.38, respectively) (Table 3). The ultimate aim of any farmer is to get more yield and return. Among the several yield components production of umbels and umbellets, which are directly or indirectly influenced by the number of seeds. Vermicompost affected the umbel number through microbial stimulation and gradual mineralization of soil. Vermicompost application through the improvement of biological activities of soil and mineral element absorption, caused more biomass production and subsequently enhanced umbel number per plant. Biofertilizers has significantly influenced the flowering and umbel number per plant. On the other hand, nitrogen fixing bacteria application through the improvement of biological activation caused more biomass production and umbel number. These findings are in accordance with the observations made by (Mahfouz and Sharaf Eldin, 2007) on Foeniculum vulgare, Sahu et al., 2013 on Coriandrum sativum and Darzi et al., 2013 on coriander.

Plants provided with RDFYM+ $75 \% \mathrm{RDN}+$ $\mathrm{RDPK}+$ Azospirillum at $5 \mathrm{~kg} \mathrm{ha}^{-1}+\mathrm{PSB}$ at 3 
$\mathrm{kg} \mathrm{ha} \mathrm{ha}^{-1}\left(\mathrm{~T}_{6}\right)$ was recorded maximum test weight $(7.35 \mathrm{~g})$, which was on par with $\mathrm{T}_{1^{-}}$ RDFYM (15 t ha $\left.{ }^{-1}\right)+$ RDNPK (90:60:30 kg $\left.\mathrm{ha}^{-1}\right) \quad(7.10 \mathrm{~g}) \quad($ Table 5$)$. The overall improvement in plant growth by cell division, cell enlargement and production of sufficient photosynthates through increased chlorophyll content of leaves on one hand and efficient utilization/ mobilization of photosynthates towards development of flowers and fruits on the other hand, might have been responsible for increased yield attributes like test weight and harvest index. This might be due to the fact that with the microorganisms are capable of mobilizing the soil bound nutrients which facilitated the availability of balanced amount of essential nutrients throughout the plant growth season resulting in better nourishment of plants and the formation of bold grains, ultimately increased the test weight. Besides biofertilizer have increased weight of 1000 seeds by enhancing the rate of photosynthesis and the biomass production improvement (Valadabadi and Farahani, 2011) on Nigella sativa, Sahu et al., 2013 on Coriandrum sativum). Maximum harvest index was recorded with $\mathrm{T}_{6}-\mathrm{RDFYM}+75 \% \mathrm{RDN}+$ $\mathrm{RDPK}+$ Azospirillum at $5 \mathrm{~kg} \mathrm{ha}^{-1}+\mathrm{PSB}$ at 3 $\mathrm{kg} \mathrm{ha}^{-1}(19.48 \%)$, which was on par with RDFYM+ $75 \%$ RDN + RDPK + 25\% N equivalent of FYM ( $\left.\mathrm{T}_{5}\right)(19.14 \%)$ and $\mathrm{RDFYM}+50 \% \mathrm{RDN}+\mathrm{RDPK}+$ Azospirillum at $5 \mathrm{~kg} \mathrm{ha}^{-1}+\mathrm{PSB}$ at $3 \mathrm{~kg} \mathrm{ha}^{-1}$ $\left(\mathrm{T}_{10}\right)(19.13 \%)$ (Table 5).

From this study it can be concluded that integrated application of both organic and inorganic nutrients are beneficial in achieving higher yield of fennel due to steady and constant availability of mineralized nutrients in rhizosphere region.

\section{References}

Aishwath, O.P. and Vashistha, B.B, 2008, Proc. Nat. Sem. on Integrated nutrient management in rainfed agro-ecosystem, held on 3-4 March, 2008 at CRIDA, Hyderabad, Andra Pradesh. pp.13.

Anonymous, 2018, Annu. Rep. (2017-18) NRC on Seed Spices, Tabiji, Ajmer, Rajasthan, India. pp. 4-5.

Arancon, N.Q., Edwards, C.A., Lee, S. and Byrne, R., 2006, Effects of humic acids from vermicomposts on plant growth. European J. Soil Biology. 42: 65-69.

Baboo, R. and Rana, N.S., 1995, Effect of cutting management, nitrogen and phosphorus on growth and yield of coriander. Indian J. Agronomy, 40(2): 253-255.

Bajya, A.K., Naruka, I.S., Rathore, G.P.S., Sktawat, R.P.S., Rajveer, Khan, S. and Sowmya, P.T., 2017, Effect of integrated nutrient management on growth, yield and quality of Fennel (Foeniculum vulgare Mill.). Intl J. Chemical Studies, 5(5): 397-399.

Bhat, V.R. and Sulikeri, G.S., 1992, Effect of nitrogen, phosphorus and potassium on seed yield and yield attributes of coriander (Coriandrum sativum L.,). Karnataka J. Agricultural Sciences, 5(1): 26-30.

Choudhary, B.R., Gupta, A.K., Parihar, C.M., Jat, S.L. and Singh, D.K., 2011, Effect of integrated nutrient management on fenugreek (Trigonella foenum graecum) and its residual effect on fodder pearlmillet (Pennisetum glaucum). Indian J. Agronomy, 59(3): 189-195.

Dadkhah, A., 2012, Effect of chemicals and bio-fertilizers on yield, growth parameters and essential oil contents of fennel (Foeniculum vulgare Miller.). $J$. Medicinal Plants and By-products, 2: 101-105.

Darzi, M.T., 2012, Effects of organic manure and biofertilizer application on flowering and some yield traits of coriander (Coriandrum sativum). Intl. J. Agric. Crop Sci., 4(3): 103-107. 
De Salamone, I.E.G, Hynes, R.K. and Nelson, L.M., 2001, Cytokinin production by plant growth by plant growth promoting rhizobacteria and selected mutants. Can. J. Microbiol., 47: 404-411.

Gad, W. M., 2001, Physiological studies on Foeniculum vulgare Mill. and Anethum graveolens L. M.Sc Thesis. Faculty of Agriculture. Kafr El-Sheikh. Tanta Univ., Egypt.

Gaur, N. K., 1998, Effect of fertility levels and Azotobactor inoculation on growth yield and quality of barley (Hordeum vulgare L.). M.Sc. (Agri) Thesis, Rajasthan Agriculture University, Jobner.

Godara, A.S., Gupta, U.S., Lal, G. and Singh, R., 2014, Influence of organic and inorganic sources of fertilizers on growth, yield and economics of fennel (Foeniculum vulgare Mill.) cultivation under semi arid conditions. J. Spices and Aromatic Crops, 23(2): 200-204.

Gomez, K. A. and Gomez, A. A., 1984, Statistical procedures agricultural research, an international rice research institute book, A Willey Inter Science Publication, John Willey and Sons, New York.

Joy, P.P., Savithri, K.E., Methew, S., Thomas, J. and Kurien, K., 2005, Effect of sole and combined application of FYM and fertilizer on growth, yield and quality of black musli (Curciligo orchioides). J. Medicinal and Aromatic Plants Sci., 27: 454-461.

Kaushik, R., Saxena, A.K. and Tilak, K.V.B.R., 2000, Selection of Tn5 lacZ mutants isogenic to wild type Azospirillum brasilense strains capable of growing at sub-optimal temperature. World J. Microbiol Biotechnol., 16: 567-570.

Khoja, J. R., 2004, Effect of sowing time and sources of nitrogen on growth, thermal requirement, yield and quality of coriander (Coriandrum sativum L.). Ph. D. Thesis Rajasthan Agric. Univ. Campus-Jobner.

Kumar, S., Choudhary, G.R. and Chaudhari, A.C., 2002, Effects of nitrogen and biofertilizers on the yield and quality of coriander (Coriandrum sativum L.). Ann. Agr. Res., 23: 634-637.

Lal, G., Aishwath, O.P. and Meena, S.S., 2009, Proc. Nat. Sem. on research needs for seed spices: issues and strategies. (Eds. Anwer et al.,) Pub. Director NRCSS, Ajmer. pp 49-63.

Mahfouz, S.A. and Sharaf Eldin, M.A., 2007, Effect of mineral $v s$. biofertilizer on growth, yield, and essential oil content of fennel (Foeniculum vulgare Mill). International Agrophyisics, 21(4): 361366.

Meena, H., 2001, Response of fenugreek (Trigonella foenum graecum) to nitrogen and sulphur management. M.Sc. Thesis, Rajasthan Agricultural University, Campus-Jobner.

Meena, H., 2005, Response of soybean to PR (34/74) incubated with non-edible oil cakes, PSB and FYM. M.Sc. Thesis, MPUAT, Udaipur.

Meena, S.S., Mehta, R.S. and Vashishtha, B.B., 2009, Influence of sheep manure, vermicompost and Azotobactor sp. on growth and yield of ajowan (Trachyspermum ammi Sprague). $J$. Spices and Aromatic Crops, 18(2): 100103.

Moradi, R., Moghaddam, P.R., Mahallati, M.N. and Nezhadali, A., 2011, Effects of organic and biological fertilizers on fruit yield and essential oil of sweet fennel (Foeniculum vulgare var. dulce). Spanish J. Agric. Research, 9(2): 546553.

Naveen, M.N., 2010, Standardization of nutrient requirement of kasuri methi (Trigonella corniculata L.) through organics. M.Sc. Thesis, Department of 
Plantation, Medicinal, Aromatic and Spice crops, University of Agricultural Sciences, Campus-Bangaluru.

Pillai, K.G., Devi, S.L. and Setty, T.K.P., 1985, Research achievements: All India Coordinated Agronomic Research Project. Fertilizer News, 30(4): 26-34.

Rahman, M.O., Babu, R.S.H. and Rao, N.S., 1990, Effect of graded levels of nitrogen on growth and yield of seed and essential oil of coriander. Indian Cocoa Arecanut and Spices J., 13: 130133.

Rai, S.K., Katiyar, R.S. and Singh, S.P., 2002, Effect of nitrogen and phosphorous on the growth and yield of (Foeniculum vulgare Mill.) on the sodic soil. $J$. Medicinal and Aromatic Plant Sci., 24 (1): 65-67.

Sahu, R., Sahu, H. and Kashyap, P., 2013, Effects of biofertilizer on the growth characters, yield attributes and quality of coriander (Coriandrum sativum). Asian J. Soil Sci., 8(2): 330-333.

Singh, S.P., 2013, Effect of biofertilizer Azospirillum on growth and yield parameters of coriander (Coriandrum sativum L.) cv. Pant Haritima. Vegetable Science, 40(1): 77-79.

Telci, I., Demirtas, I. and Sahin, A., 2009. Variation in plant properties and essential oil composition of sweet fennel (Foeniculum vulgare Mill.) fruits during stages of maturity. Indian $J$. Crops Production, 30(1): 126-130.

Tiwari, R.J. and Banafar, R.N.S., 1995,
Application of nitrogen and phosphorus increases seed yield and essential oil of coriander. Indian Cocoa, Arecanut and Spices J., 19(2):51-55.

Tripathi, A.K., Pandy, R.K. and Tripathi, M.L., 2001, Effect of nitrogen, phosphorus and potassium on stem gall disease and yield of coriander. Ann. Plant Protection Sci., 9(2): 337-339.

Vadiraj, B.A., Siddagangaiah, S. and Narayana, S. P., 1998, Response of coriander (Coriandrum sativum L.) cultivars to graded levels of vermicompost. Journal of Spices and Aromatic Crops, 7(2): 141-143.

Valadabadi, S.A. and Farahani, H.A., 2011, Investigation of biofertilizers influence on quantity and quality characteristics in Nigella sativa L. J. Hort. Forestry, 3(3): 88-92.

Yadav, R.D., 2005, integrated nutrient management in coriander (Coriandrum sativum L.) under loamy sand soils. Ph.D. Thesis, Rajasthan Agricultural University, Campus-Bikaner.

Yadav, R.D., 2005, integrated nutrient management in coriander (Coriandrum sativum L.) under loamy sand soils. Ph.D. Thesis, Rajasthan Agricultural University, Campus-Bikaner.

Zaller, J.G., 2007, Vermicompost as a substitute for peat in potting media: Effects on germination, biomass allocation, yields and fruit quality of three tomato varieties. Scientica Horticulture, 112: 191-199.

\section{How to cite this article:}

Kusuma, M.V., J. Venkatesha, P.M. Ganghadarappa., J.S. Hiremath, A.B. Mastiholi and Manjunatha, G. 2019. Effect of Integrated Nutrient Management on Growth and Yield of Fennel (Foeniculum vulgare Mill.). Int.J.Curr.Microbiol.App.Sci. 8(01): 2782-2794. doi: https://doi.org/10.20546/ijcmas.2019.801.293 